\title{
IDEOLOGY AND THE GRAMMAR OF IDEALISM: THE CATERPILLAR CONTROVERSY REVISITED
}

by Peter Armstrong.

University of Leicester

Contact Details

Professor Peter Armstrong

The Management Centre

University of Leicester

LE1 7RH

E-mail p.armstrong@le.ac.uk 


\begin{abstract}
Methodological idealism is attractive to the ideologue because of the freedom it offers to construct a preferred story-line. This means that the realist critique of such writings tends to coincide with a critique of ideology.

This paper revisits a recent exchange along these lines within the literature of critical accounting. The occasion was Miller and O’Leary's (1994) proclamation that a 'new economic citizenship' had come into being with the spatial re-organisation of manufacture at the now defunct Decatur plant of the now defunct Caterpillar company. A first critique by Arnold (1998) demonstrated that this version of events could not be reconciled with the experiences of the workforce. A second, by Froud et al. (1998) pointed out that it was actually based on an uncritical recycling of management representations of their own actions. A more adequate understanding, both of the accounts and of the actions needed to situate both in relation to the company's competitive situation. Though both critiques commented on the stylistic devices employed in Miller and O’Leary's narrative, neither of them, understandably, made any detailed analysis of their role in arguing Miller and O'Leary's most spectacular claim: that there was some kind of 'linkage' between the changes in the layout of Decatur's shopfloor and a new economic citizenship for the workforce.
\end{abstract}

Because Miller and O'Leary's manner of 'writing the social' has now become a dominant force within the critical accounting project, it is important to examine the manner in which it achieves its truth-effects. On the evidence of the Caterpillar paper at least three stylistic devices are heavily involved:

A persistent tendency to write in the passive voice fudges the issue of who thought and did what. A first consequence is that management images of the state of mind of the workforce are all-too-easily taken to be primary evidence of what these states of mind were. A second is that the narrative fails to distinguish interpretations made by the people at Decatur from the authors' own.

The widespread use of key terms in scare quotes, creates uncertainties about whose definitions of them are at issue and what those definitions are. The result is a terminological slack which allows the authors to argue at will the linkages and connections (also undefined) on which their thesis depends.

A preference for writing about control systems in terms of the personal characteristics which they assume results in a narrative in which hypothetical beings (e.g. 'the governable person') are repeatedly invoked and gradually take on a quasi-corporeal existence in the process. Modes of 'governmentality' then appear to produce their intended effects simply in virtue of their existence.

Taken together, the effect of these rhetorical devices is to allow the empirical world to speak in evidence, but only as scripted by the authors. In this manner, the warrant of empirical research is attached to a preferred vision of the social. The result is ideology. 


\section{Introduction: Idealism and Ideology}

One of the pleasures of imaginative writing is the freedom which it allows for a parallel world to be created embodying the predilections and purposes of the writer. That freedom, paradoxically, depends on the normative constraints attending the public creation and renewal of language. The parallel worlds of fiction, that is, are realised through a medium which depends for its vitality on a constant effort on the part of ordinary users of language to make sense of things which are not language. Because the language itself is continually twisting in other directions and under other influences, this effort too calls for creativity and imagination, just as much perhaps as self-conscious imaginative writing. In this analogue of tendencies in social science, the writers of fiction are the idealists and the public are the realists.

For some, idealism is now the general condition of social science. Following the implosion of positivism, the 'crisis of representation' in anthropology (Taylor, 1999) has led some of its more excitable practitioners to the conclusion that there is no essential distinction between works of fiction and non-fiction (e.g. Denzin, 2000). Because sociological accounts cannot be independent of the methods used to produce them, so the argument runs, we must recognise that they are nothing but the product of those methods. Instead of writing of the social world as we formerly thought, we must recognise that we construct it as we write. For some, the logic has led to the presentation of self-declared works of fiction as ethnography, culminating in the 1972 award of a PhD in anthropology at the University of California for Carlos Castaneda's description of his imaginary experiences with a shaman called Don Juan (Times Higher Education Supplement, 2001). The flaw in this evidently seductive line of thought lies in the fact that the methods of genuine sociological enquiry do not guarantee their findings in advance of their engagement with the empirical. They define the terms of that engagement, but they do not determine its outcome. If they can be shown to do so, we are entitled to conclude that we are indeed in the presence of fiction - and it is precisely the object of this paper to argue that this is the case with some aspects of Miller and O’Leary's (1994) study of Caterpillar.

That study, however, like most products of the idealist tendency, was not a selfdeclared work of fiction. Rather, it built its account from the conventional materials of ethnography, documents, statements and descriptions of events. As is also conventional, one is tacitly asked to accept that the documents existed, that the statements were made and that the events took place, not just in Miller and O'Leary's account, but in a world external and prior to it. These materials, in a word, were presented as evidence, more precisely as evidence in support of a particular account of Caterpillar. Their paper therefore makes a truth-claim, not the positivist dream of a single truth written by the evidence, but the more modest claim to have produced a reading of the case consistent with its own reading of that evidence. It is here that the present paper takes issue with Miller and O'Leary's study. At crucial points, it will be argued, the articulation of evidence and interpretation in their paper is more one of appearance than substance. A variety of linguistic devices is employed to juxtapose the two, but to do so on terms which allow the Miller and O'Leary almost unlimited freedom to project a preferred vision of the social order onto their case. In this respect their study is idealist. The result, not throughout their paper but at important points, is substantive fiction with the appearance of empirical research. In that respect, their study is also ideological. 


\section{Miller and O'Leary: The Plant With A Future}

Millar and O'Leary's paper concerned a re-organization of the Caterpillar company's plant at Decatur, Illinois (Miller and O’Leary, 1994). The programme, which began in 1986, was called 'Plant with a Future' (PWAF) and, at the time of the research, it was the latest of Caterpillar's response to losses totalling almost $\$ 1$ billion in the preceding three years. During that three years the company had closed six US plants, reducing the headcount of hourly paid workers by $44 \%$ and that of salaried staffs by $26 \%$.

PWAF itself contained an implicit threat of more job losses. In order to avoid identification as a plant without a future, Decatur had been required to undertake subprogrammes of product simplification, manufacturing automation and the integration of its information systems around a system of cell manufacture. Materials and components for each cell were delivered via an 'Assembly Highway' to which the completed product was returned for delivery to the next stage of manufacture, or to the paint shop in the case of the final stage. Within the cell teams, flexible working had been introduced, with the teams themselves taking responsibility for quality. In order to ensure this, there was no provision for rectification work outside the cells and no buffer stocks were held. Manufacturing Resource Planning (MRP) software coupled all manufacturing schedules to orders from specific customers, and progress against these schedules was shown on a computer monitor installed in each cell. At the same time, costs and build times were benchmarked against those of Komatsu, then considered a major competitor. Red and green lights in each cell showed whether the process was ahead of its benchmark or behind it. Meanwhile 'non-core' manufacturing processes (generally those which were simple and labour intensive) was outsourced to 'focussed, low-cost suppliers'.

All of these changes were accompanied by a great deal of managerial communication on the subjects of competitiveness and responsibility to the customer. Wanting Caterpillar employees to experience competition at a personal level, senior executives put it about that 'there's a person at Komatsu who is doing the same job as you are doing at Cat,' and it was this message that the red and green lights were intended to convey. Similarly the cell teams were to think of the units on which they worked as having already been sold to identified customers, and in order to encourage this, the customers' details were displayed on the computer monitors alongside the MRP.

This much is fact. The declared object of Miller and O’Leary's paper, however, was to present an analysis of these facts, one through which they would be able to offer an understanding of 'the dynamics of a specific attempt to govern the economic and personal dimensions of an enterprize'. Their Abstract proposed to do this by pursuing three distinct levels of analysis: that of the interlinked changes in manufacturing process, management techniques and spatial arrangement at Decatur, that of the general talk of 'advanced manufacturing' as a means through which the USA might compete with Far Eastern imports and its actualisation at Decatur, and that of the links between the re-organization and the discourse of 'economic citizenship' which had come to be associated with advanced manufacturing. It was through an exploration of the 'links and relays' between these levels of analysis (which themselves contain linkages between discourse and practice) that the authors sought to understand 'a new mode of seeking to govern economic life', one in which 'a novel type of economic citizen is called upon to play a new set of roles within the enterprize and within the nation'. 
Some parts of this thesis, it should be said at once, are convincing. One does not need much persuading that the introduction of cell manufacturing at Decatur, and indeed the re-organization in general, were influenced by general discourses of advanced manufacturing. Though (oddly) the authors did not stress the fact, they mentioned at one point that management consultants were involved, and it would be surprising if these did other than import the currently accepted success recipes. Similarly it is not hard to believe that the communications of Caterpillar's management on the subjects of competition and customer focus tapped into wider discourses on these matters, and that these were indeed behind the design of the information fed to the cell teams by the computer monitor and coloured lights. On these points, Miller and O’Leary's paper was well-documented, convincingly argued - and unexciting. They were not, however, its main thrust. What grabbed the attention of the general reader, and that of the critics to be introduced presently, was the significance which the authors attached to what they refer to as 'the spatial re-ordering of manufacture' - the changed plant layout. They claimed that the managerial re-organization of Decatur, including the new plant layout and visibly symbolised by it, amounted to nothing less than a new economic citizenship. Though the fine print of the paper pointed out the potential fragility of this conclusion, adding that the "position and meaning of the various components [of the re-organisation and the talk associated with it]. . are mobile and shifting', it nevertheless was the conclusion. As such, it provoked two substantial critiques, both of which were published in 1998, together with Miller and O'Leary's reply.

\section{Arnold: the View from the Union Hall}

By the time Miller and O'Leary's paper appeared in print, the Caterpillar company had become embroiled in a protracted series of strikes. The occasion of Arnold's critique (Arnold, 1998) was the inconsistency between this turmoil and Miller and O'Leary's contention, however hedged about with qualifications, that the conditions they had witnessed at Decatur could be described in terms of economic citizenship. More broadly, she objected to their version of the critical accounting project on the grounds that it ignored the embedding of management and accounting technique in the distributional conflict between capital and labour. From that point, her procedure was classically realist. In effect she treated Miller and O'Leary's conclusions as an hypothesis and took them back to the data. If there was something which might be described as economic citizenship at Decatur, it should be experienced as such by the workforce. The strike was prima facia evidence that there was not. The experiences of trade unionists, as she put it, were asking questions of a theory which portrayed their conditions in terms of economic citizenship. She proposed to report their findings through a series of interviews with members of the United Auto Workers Union Local 751 - the Decatur plant.

Miller and O’Leary themselves appear to have interviewed very few workers in the course of their research and most of those appear to have been shift supervisors.

Management sources, in contrast, are quoted extensively, sometimes from interviews, but more usually from in-house publications and what appear to be press releases. Miller and O'Leary's account of events at Decatur, in consequence, is actually an account of management accounts. Theirs is an attribution of citizenship which pays little attention to the views of the citizens themselves.

Arnold's interviews revealed a number of discrepancies between the stories of the reorganization offered by management and the workers' experience of them. For them, 
the organising theme of the various management initiatives was the loss of jobs. Flexibility meant increased workloads - rather than autonomy - and job losses. Training to do other people's work was challenging and interesting, but it threatened these others' livelihoods. The workers originally co-operated in combating foreign competition by finding more cost-effective ways of doing things and beating production targets. Experience soon showed, however, that this would often be followed by the transfer of work to other plants - and job losses. As for cell proprietorship, yes, it gave more control over the actual tasks, but it cost jobs. Such interpretations are scarcely surprising in view of the precipitous decline in employment at Decatur - from 4,600 in 1979 to 1,800 in 1995. The training, the flexibilities, the increased autonomy and responsibility which read as citizenship to Miller and O'Leary added up to increased workloads and insecurity as far as the workers were concerned. Considered as social theory, the management rhetoric which accompanied the changes at Decatur simply failed to account for what the workers found most significant in their data. Expressing their consequent cynicism, they began to invert the managerial acronyms which had accompanied the Plant With A Future programme. When a security perimeter had to be erected around the plant to keep out labour protesters, for example, PWAF began to mean 'Plant With A Fence'.

Arnold also observed that Miller and O’Leary's study took place during an uncharacteristic period of industrial peace, precisely the period during which Caterpillar's management needed the co-operation of the workforce in setting up the new working arrangements. Whilst Miller and O’Leary cannot of course be criticized for the timing of their research, subsequent events cast doubt on their benign interpretation of what was going on during this period.

In 1991, the company approached the contract negotiations demanding a reduction of job protection rights. A failure to agree led to a protracted strike which was finally broken by threats to permanently replace the strikers. Following this defeat for the workforce, flexible work schedules were imposed which abrogated the eight-hour day hitherto regarded as a custom-and-practice right. A later strike over unfair labour practices also collapsed whereupon the company imposed a two-tier wage structure with lower pay for new hires, an expansion of part-time and temporary working, greater management control over the content and timing of work and a further weakening of job protection clauses. Some of the strikers were dismissed whilst others were placed under an order restricting their rights to discuss the strike and to participate in trade union activity. Faced with the fact of this managerial roll-back of the frontier of control, Miller and O'Leary could - and did - argue that they had themselves pointed out the fragile and temporary nature of alignments between ideas and practice. This is quite true, but it is an argument which rather sells the pass. If citizenship rights are as easily clawed back as these later events demonstrated, they are not rights at all. Whatever was driving the new hard line in industrial relations and the critique of Froud et al is illuminating in this respect - it was certainly not respect for the rights of citizenship.

\section{Froud et al: a Second Story}

Froud, Williams, Haslam, Johal and Williams (1998) too point out that Miller and O’Leary's paper relies almost entirely on management sources. In fact its empirical part, they point out, consists largely of a translation of management documents into a highly specialized language which has evolved in the conceptual rain-forests of postFoucaultian scholarship. To Froud et al, the primary characteristic of this language is 
'immunisation'. Accounts written in it, that is, are immunized, first from identification with any particular value position, and second from the possibility of contradiction.

The first is achieved by presenting socially consequential concepts - such as economic citizenship - in quotation marks so as to signal that the authors are not to be construed as endorsing them. At the same time they are presented without comment, so as to give no grounds for an inference of dissent. Immunisation from consequences meanwhile is achieved through the employment of a language of mobility and indeterminacy to connect the terms of description. The result has something in common with the prophecies of Nostradamus. The meaning of terms is open, anything is possible and nothing can happen which is not foretold

A second element of Froud et al's critique concerns the partiality of Miller and O'Leary's treatment of the relevant literatures. It is that on the social consequences of advanced manufacturing which most concerns us here. In Miller and O’Leary's representation this has reached an authoritative consensus on the benign concordances between the requirements of competitiveness, the practices of advanced manufacturing and the new economic citizenship. Against this, Froud et al point out that recent work in the field suggests that advanced manufacturing technology is leading to a new duality of labour markets in which anything which might pass for a new economic citizenship will be restricted to a 'fortunate fifth' of 'symbolic analysts' with the rest abandoned to direct competition with the world's low-wage economies. The relevance to those Caterpillar workers who found re-employment in the companies to which their work had been outsourced is obvious. And so is the relevance to Miller and O’Leary's story.

The third part of Froud et al's paper uses an analysis of financial and accounting data to situate the actions taken and the stories told by Caterpillar's management against the company's competitive and market situation. In the terms of Bhaskar's realism (1986), the mechanics of product market competition are taken to be a reality which obtrudes into the realm of the empirical through its influence on management talk and action.

There are two main findings. Firstly that the threat of competition from Komatsu during the early 1980s had more to do with a favourable Dollar-Yen exchange rate than any advantage in productivity, and that the threat had largely evaporated by the late 1980s. Secondly, Caterpillar's response to this partly temporary and partly imaginary threat saddled the company with the problem of recovering the costs of a huge investment in automated machinery in a largely static product market. This could only be done by attacking labour costs, and it was this which lay behind the intransigent attitude with which management approached the 1991 and later contract negotiations.

\section{Miller and O'Leary: Finding Things Out}

As is the norm in academic life, Miller and O'Leary's response (1998) combined an obdurate defence of their paper with a petulant counter-attack on their critics. Far from giving the lie to their account of the Caterpillar re-organization, the industrial strife which followed it had been allowed for, anticipated even, in their emphasis on the fragility and mutability of the linkages between discourse and practice. The new economic citizenship could just as well 'mean' a hard line in industrial relations as a managerial willingness to bargain for co-operation. 
They objected, moreover, to their critics' contention that management talk and action could only be adequately understood against the system logic of capitalism. This was dogma, with 'the whiff of the gulag' about it. The re-organization of Caterpillar had to be understood as a programme. As such its design and re-design were not reducible to the conditions to which they were a response. That was why Miller and O'Leary had listened to management, something which their critics had notably failed to do. Arnold had only interviewed union representatives whilst Froud et al had based their analysis entirely on published financial data. Despite this inadequate empirical basis, both of them had felt able to pass judgement on the actions of Caterpillar's management. They could only do so because, gripped by dogma, they knew the answers in advance. Miller and O'Leary themselves, in contrast, had approached their subject with an open mind. As the title of their response claimed, they were interested in finding things out.

Remarkably, for authors so steeped in the writings of Michel Foucault, this last remark is a fair approximation to the positivist credo. As such it cries out for amplification. Meanwhile, as we shall see, it is very much at variance with Miller and O’Leary's practice.

The rest of their response fails to recognize that their critics were as much concerned to correct imbalances in their work as to offer substitute analyses of their own. The objection was not to Miller and O'Leary's attention to management, but that they only attended to management. Similarly, the argument was not that the dynamics of capitalist competition could account for the fine detail of management programmes, but that such programmes can only be adequately understood as responses to these dynamics. Nor was there an objection to Miller and O'Leary's stress on the fluid nature of the links between the discourse and practice. The objection was that instead of exploring the nature and limits of this fluidity, it was functioning at the rhetorical level as a post-hoc reconciliation of new economic citizenship with whatever took place at Decatur. Links of this nature are indeterminate to the point that they tell us nothing about the limits of what can be done in the name of new economic citizenship.

\section{A Cell of One's Own}

The simultaneous stress on the importance of links between discourse and action as a path to understanding, and on the indeterminacy of these links raises acute problems with the manner in which Miller and O'Leary read their data. What are these 'linkages', 'alignments' and 'congruencies' which figure so prominently in their vocabulary? Are they such that discourse can be demonstrated to influence action or vice-versa? And if they are not, how can we know of their existence?

As a preliminary approach to this question, let us examine the author's treatment of the notion of cell proprietorship. Though not co-extensive with the new economic citizenship, it is a key component of it. Unlike the broader concept, moreover, it was a form of words actually used by Caterpillar management, so we are not troubled with the prior question of why it figures in the analysis at all. What did cell proprietorship mean to Caterpillar's management, and how was it operationalized?

Individual manufacturing cells or modules were to be understood as “small businesses", spaces for collective entrepreneurship by the groups of workers within them, the "cell proprietors". Each cell would manufacture a sub-product from start to finish, with work sequenced in a continuous 
programmed flow within the cell, and set to performance standards measured against Caterpillar's most demanding foreign competitors.

Miller and O’Leary (1994)

Small businesses - but with flexible working, production schedules and standards all imposed from outside. As we have seen the 'entrepreneurs' were also assisted by red and green lights installed in each cell, a green signifying that the process was on schedule to beat the benchmark time derived from competitor cost analysis, and a red that it was behind. In addition, a computer terminal in each cell called the 'cell proprietor interface' carried details of the specific customer order on which the cell was working, together with the target completion times computed by the MRP software. The declared intention of Caterpillar management was to make competition with Komatsu and the satisfaction of each named customer the business of every individual worker.

How we are to understand the linkage between these arrangements and management's use of the term 'cell proprietorship' to describe them? In ordinary language, proprietorship means something like:

Proprietor: One who holds something as property; one who has the exclusive right or title to the use or disposal of a thing; an owner

Shorter Oxford English Dictionary 1960

But in the cells of Decatur, there was no ownership of property, and nor was there exclusive right or title. It was only the responsibility for confronting competition and for satisfying customers which was 'owned', a meaning which coincides with what Friedman (1977) called 'responsible autonomy'. But responsible autonomy is a control strategy, not a softening of the property rights of the capitalist corporation. The rights are those of flexible working; at a higher level the freedom to find new ways of achieving the objectives of the company, and at a lower level to find new ways of achieving the targets derived from them.

This chewing at the concept of proprietorship so that it becomes formless enough to wrap around that of responsible autonomy is, of course, neither new nor innocent. The 'responsible' part of Freidman's couplet implies an internalisation of commitment which cannot be assumed as given. It is something for which managements need to work at the level of ideas - hence Edwards' (1979) alternative term of 'hegemonic control'. Part of that work, work into which the localized discourses of Decatur were able to tap, has been a decades-long re-working of the terminology of ownership to cover a devolution of responsibilities which carries with it only a single right - the right to receive blame when things go wrong. This, to be sure, is a 'linkage' between discourse and practice, but it is a linkage which implies no constraint whatsoever on the practice. It is misdescription, pure and simple. Ideology. Spin. Insofar as this is the case, and Miller and O'Leary offer no evidence that it is not, the talk of cell proprietorship at Decatur tells us nothing at all about the working arrangements to which it was applied.

\section{Importing Economic Citizenship}

As Froud et al point out, Miller and O’Leary's writing is marked by a persistent tendency to enclose their key concepts in quotation marks, notably that of new economic citizenship. This matter will be explored in more detail in a moment. For 
now, the point is that these quotation marks do not seem to denote direct speech. There is no point in the paper where the authors clearly state that the words 'new economic citizenship' were uttered by an interviewee, or written in a management document. This being the case, we are entitled to assume that it is a concept imported into the analysis by the authors, and to ask on what basis it has been imported.

Pure-minded ethnomethodologists object to the importation of observer categories into social analysis on the grounds that they involve interpretation, are therefore subjective, are therefore not reproducible and - again therefore - are unscientific. For some of them, it is a logic which ends in the madhouse of conversational analysis. For the rest of us, learning to apply observer categories as they are habitually employed in our speech communities is part of the normal process of language acquisition (Hesse, 1974). The ethnomethodologists, nevertheless, have a point in that the importation of observer concepts needs justification. What, then, is Miller and O'Leary's warrant for discussing the Decatur re-organisation in terms of economic citizenship? Why does it figure in their analysis at all?

If anywhere, the justification is to be found in the literature review which immediately precedes the case. Miller and O’Leary's first source for the concept was the 1989 report of the MIT Commission on Industrial Productivity (Dertouzos, Lester and Solow, 1989). As the term was used in that report, the new economic citizenship turned out to be remarkably similar to conventional 'enlightened' human resource management. The ingredients were a well-educated workforce properly appreciated and rewarded, continuous training, the devolution of responsibility, teamworking, networking and self-government. The coincidence, of course, was no coincidence. Theoretically modest though practically ambitious, the relevant part of the commission's objectives was precisely to identify 'average' employment practice in America's most competitive manufacturing companies. New economic citizenship was simply the form of words chosen to refer to the ensemble of these practices. The element of arbitrariness was emphasized in a later publication (Dertouzos, 1997, pp. 212-3) which listed international variations in the terms used to describe essentially the same conditions. 'Human Capital' was the accepted term in Sweden, 'Toyotism' in France and 'Human Ware' in Japan (where perhaps they know a little bit more about Toyota than the French). In other words, Miller and O'Leary's citation of the Commission's report is evidence not so much of a change in practice but of a change in the preferred description of (relatively conventional) practice.

Sensing an uncertainty of footing perhaps, the authors sought additional justification in the literature on Flexible Specialisation. Inevitably brief, their review was also highly tendentious, relying as it did on contestable secondary interpretations of the source researches (mainly Sabel, 1991 and Hirst and Zeitlin, 1991). Many of these provide no warrant whatsoever for describing employment conditions in the 'Third Italy' and other industrial districts in terms of economic citizenship. The networks of flexible specialists always depended in part on the exploitation of unofficial labour (Inzerilli, 1990; Blim, 1990, p. 237), and they were often themselves the exploited subcontractors of larger companies (Blim, 1990, p. 124). Even where this was not the case, the original pseudo-egalitarian networks of mutual contracting tended, through the mechanics of competition, to degenerate into centrally administered systems of subcontracting, on the model of Benetton (Harrison, 1994).

Even supposing the new industrial districts offer a plausible model for industrial citizenship, their relevance to the case of Caterpillar is doubtful. The industries in 
which they have appeared serve fashion markets such as furniture, footwear, ceramics and clothing - markets in which rapid responses to changing tastes are more important than the containment of production costs (Amin, 1989). Hence the need for a skilled workforce able to turn out customised products at short notice using general-purpose machinery. Caterpillar, in contrast, produced heavy earth-moving machinery - not ordinarily a fashion item. The company was attempting to compete moreover, not by offering customised products, but by reducing costs.

These, then, were Miller and O’Leary’s warrants: a Commission which almost arbitrarily used the term 'economic citizenship' to refer to conventional 'soft' human resource management (Storey, 1992), and a selective reading of a marginally relevant literature. By presenting these fragments as an authoritative consensus on broad trends in US advanced manufacturing, nevertheless, it was made to appear quite reasonable that the account of Caterpillar should be framed through the concept of economic citizenship.

\section{Through the Quotation Marks}

Miller and O'Leary did not seem to understand their critics' concerns about their promiscuous use of quotation marks. They used them, they said, 'because we wish to tell the reader what others have said.' The problem is that they rarely tell us which others.

Their persistent enclosure of new economic citizenship within quotation marks is a case in point. As indicated a moment ago, this does not appear to indicate direct speech. But if that is the case, what does it mean? Perhaps an experiment will help. Consider the following sentences:

Peter Miller is a professor at the London School of Economics

'Peter Miller' is a professor at the London School of Economics

Peter Miller is a 'professor' at the London School of Economics

The proper noun becomes improper whilst the common noun becomes commoner still. In both cases we have an imposter, the first of an individual and the second of professors as a species. Taken together, the examples suggest that the quotation marks enclosing new economic citizenship may signify falsehood or irony, that something is being passed-off as citizenship which would not be described as such if words were used in their normal sense. By now it will be evident that the writer thinks that this is the case, but do Miller and O’Leary?

The indications are that they do not. There are no contexts in the paper which contrast conditions in Caterpillar or anywhere else with the meanings which Miller and O’Leary attach to new economic citizenship. Unless we are meant to infer that information on competitor costs and the devolution of responsibilities for production adds up to citizenship, in fact, Miller and O'Leary offer little elaboration of what it might mean anywhere in their paper. The mask of irony, if irony it is, is sustained throughout. A second problem with the 'misrepresentation' hypothesis is that no-one is identified as doing it. We are told that beliefs in, or ideals of, new economic citizenship are held, but we are never told by whom. For example:

'A third level of analysis concerns the linkages between the spatial reordering of production processes at Caterpillar's Decatur plant and the claim that the design of advanced manufacturing 
facilities offers a key opportunity to give shape and form to a "new economic citizenship"

(Dertouzos et al., 1989, p. 134). This image of a "new economic citizenship" has been held to consist in a potential empowerment (Johnson, 1992) of shopfloor workers, supervisors and middle managers .

Miller and O’Leary (1994)

Slippery stuff! Anonymously held images of economic citizenship are held, also anonymously though perhaps differently so, to consist of potential empowerment. Not actual empowerment, mark you, but the potential for it. A potential to be activated by someone other than the potential empower-ee presumably, otherwise that would amount to actual empowerment. There are severe problems in tracing responsibilities here, but not irony, so far as can be told, and not an implication of misrepresentation.

A second possibility is that the quotation marks signify that unfamiliar meanings are attached to the words. Normal procedure if this were the case, would be for the phrase to be introduced in quotation marks along with a definition of the particular sense in which it is to be used. The quotation marks would then be dropped on subsequent occasions. Arguing against this reading, though not conclusively so, is the fact that Miller and O'Leary carry on with the quotations marks without clarifying what they mean.

A third possibility is that the use of the quotation marks signifies meanings which other people attach to new economic citizenship, with the authors themselves abstaining on the questions of their validity or legitimacy. This reading potentially overlaps the second, since these others may also be using the phrase in an unfamiliar sense. Such a reading, in all its ambiguity, is supported by the contexts, with the foregoing quotation as an example. On the few occasions when new economic citizenship occurs without quotation marks, moreover, Miller and O'Leary refer to it not directly, but as a claim made by anonymous others, or as an ideal to which these anonymous others appeal.

\section{Truth Claims of the Third Kind}

This partial clarification unfortunately, only leads to a new impasse. For if the meanings attached to new economic citizenship are those of other commentators (presumably including the MIT Commission and the cited writers of the 'flexible specialisation' school) it is Miller and O'Leary themselves, not these commentators, and not, assuredly, people at Decatur, who attach these meanings to intentions, events and objects at Decatur. And this occurs precisely at the crux of their paper. The promise to establish connections between the spatial layout of production and the new economic citizenship is its hook, its McGuffin, its Unique Selling Point. Consider, then, the interpretation of the introduction of cell manufacturing at Caterpillar, and the physical connection of these cells via an 'Assembly Highway'.

Practices of synchronous flow manufacture had been deployed. The production process was declared to have been consolidated, simplified, modernized, rendered flexible and extensively automated. In making operable these general principles for the design of manufacturing processes, the Assembly Highway gave form to hopes of a new competitiveness and a new mode of economic citizenship in American industry.

Miller and O’Leary (1994)

Whilst 'hopes of,' as form of words, contracts out the conceptualisation of economic citizenship, it is Miller and O'Leary themselves who declare that the Assembly Highway embodied these hopes. But on what basis can they make such a claim and on 
whose behalf are they making it? Physically speaking, the Assembly Highway was nothing more than a linear space on the factory floor with the manufacture and assembly cells branching off it. Miller and O'Leary's persistent use of the passive voice gives no clue as to who is supposed to have attached to it the significance which they claim; nor do they provide us with evidence that anyone does so. They simply state that it is so. It cannot be the 'commentators' who talk of economic citizenship, since these were commenting on American industry in general, not Caterpillar in particular. Nor is it anyone at Caterpillar, since the concept was not in use there. We are left with the authors themselves - and this, we suddenly realize, is why we are presented with no evidence. None is needed, since what better authority could there be on the mental states of the authors than the authors themselves?

In the terms of Habermassian linguistic pragmatics, we are in the presence of truth claims of the third kind, not the first. Claims, that is, of sincerity rather than factual accuracy. Assertions of this nature run through the whole of Miller and O'Leary's attempt to link the 'spatial re-ordering of manufacture' with the ideals of new economic citizenship:

In transforming the relationships between the different stages of the production process, and in envisioning the process as a whole in system terms, the Assembly Highway gave form to the ideals and aspirations contained in a particular notion of the "customer". In so doing, the Assembly Highway made possible a temporary and fragile stabilisation of that "new economic citizenship" appealed to by so many commentators.

Miller and O’Leary (1994)

Again it is new economic citizenship as imagined by 'commentators' which is at issue. But again it is Miller and O'Leary themselves who declare that the Assembly Highway embodied (for themselves) a particular notion of the customer and thence these commentators' meanings of new economic citizenship. The same trope of unsubstantiated assertion occurs in their interpretation of the manufacturing cells. In these, they tell us:

. . all manufacturing work was to be arranged in product and sub-product dedicated "cells" or modules. The individual's contribution to an overall process or product might be made self-evident in the spatial arrangement and sequencing of manufacturing activities. The ideal of a "new economic citizenship" could thus be embodied in a distinct spatial arrangement of the factory floor.

Miller and O’Leary (1994)

Within the critical accounting literature, as elsewhere, spatial arrangements which expose the performances of individuals to this kind of surveillance are more usually apprehended through the metaphor of the Panopticon than one of citizenship. But Miller and O’Leary are in the grip of an idea, and what they are doing is sincerely reporting that fact.

On this point we can see that Miller and O'Leary's reading of their case is quintessentially idealist. Objects and events enter the reading, that is, not as the subject of contingent statements, but as the raw material for feelings of symbolic harmony. Although they feed upon empirical data, as romantic poetry feeds on landscape, such interpretations make no publicly verifiable statements about it. Instead they absorb it in the manner of a black hole, emitting only a vague radiation to mark its assimilation. What would it take, for example, for the Assembly Highway not to embody the idea of economic citizenship, or for it not embody an ideal of the customer? What, then, does it mean to say that it does? 
Interestingly, this idealism does not run consistently through the whole of Miller and O'Leary's paper. Their assertion of linkages between competitiveness and the communication of information on competitor costs, like all theorisations, is a mental construct and its application to the empirical data involves interpretations. The crucial difference is that these interpretations allow for the possibility of inconsistency with the mental construct. The traffic lights which measured Caterpillar performance against the Komatsu benchmark were not, by definition, installed with the specific intention of personalising competition. It was the contingent fact that management also spoke of doing this which (more or less) justifies that interpretation. This methodological unevenness raises the interesting possibility that Miller and O’Leary's paper works at the level of rhetoric by a kind of osmosis of credibility. Its relatively mundane excursions into realism perhaps serve to lay down a mood-music of assent which then spills over into their more spectacular but less substantial claims.

\section{Enactment and Operationalism}

As well as explicating the metaphoric significance of machine layouts, Miller and O'Leary were concerned to trace linkages between the new economic citizenship and other aspects of work at Decatur. Everything which has been said about their claims for the significance of spatial re-organization applies equally here. The claims of linkage are made entirely by assertion and concern relationships which exist only in the minds of the authors. The difference this time is that the alleged connections are not of symbolic significance, but that conditions at Decatur constituted an enactment of new economic citizenship. This adds a new dimension to what they have to say because it involves the attachment of an operational meaning to the concept. Because it is left undefined throughout their paper, it becomes a form of words which can be attached to the conditions which they actually observed.

In everyday language, the enactment of a principle or plan refers to a flow of influence running, in the first instance at least, from ideas to action. There is a mental map of greater or lesser definition which is operationalized in the realm of the real. In practice, to be sure, implementation, like politics, is (sometimes) the art of the possible. There may be a blowback, as it were, so that principles and plans are modified in the course of implementation. Enactment, nevertheless implies that what is done is guided or constrained by that which is to be enacted. Miller and O'Leary's talk of linkages between discourse and practice, indeed, raises expectations that precisely this will be discussed.

In the case of the competitiveness/new manufacturing couplet and the Caterpillar reorganization, this is exactly what we get. General discussions and previous models of cell manufacture, flexibility and consciousness of the customer and competition are all shown to be articulated by Caterpillar's management and implemented in their reorganization. But this treatment is not paralleled in the case of the new economic citizenship. Here Miller and O’Leary seem to mean something rather different by enactment. Explaining their reticence on the question of what new economic citizenship might mean, perhaps, they write as if the concept is somehow empty until it is given empirical content:

It is the novel arrangements of persons and things on the factory floor, the new ways of making calculations of the spaces thus formed, and the distinctive conceptions of the capacities and attributes of individuals who are to occupy such spaces, that gives content to the notion of "new economic citizenship”. 
New economic citizenship here begins to take on the look of a Baudrillardian freefloating signifier. There is no sense of limits to the concrete arrangements to which it can be attached. The 'linkage' between words and action is simply that the former are attached to the latter. Again:

Experts of varying kinds translate concerns with competitiveness, productivity, flexibility, and cost structures into working arrangements on the factory floor. In the process, they help to constitute and make operable modes of economic citizenship.

Miller and O’Leary (1994)

Notice that the concerns which are translated in this passage are all about economic performance and the control of labour, not about citizenship. No-one would dispute that Caterpillar's re-organization was driven by plans and principles which were intended to restore the company's profitability. The point as issue was whether they were also influenced by concerns about citizenship. As has been noted, new economic citizenship as an actual form of words does not seem to have been in use at Caterpillar, but it is still possible that the re-organization was influenced by concepts which added up to something similar. What were these concepts, we need to know, and is there evidence that they were anything more than an empty rhetoric designed to make the re-organization more palatable to the workforce, the public and to academic researchers?

Despite Miller and O’Leary's repeated reference to ideals of new economic citizenship, the notion that principles gain content only in their practical application is actually the stance of operationalism. Operationalism as a creed is attractive to selfstyled practical persons; people, that is, whose practicality consists in running things as they are. This is because it ensures that ideas only count when they are incorporated into concrete social arrangements. The fact that these arrangements are controlled by the aforesaid practical persons means that potentially awkward ideas (such as new economic citizenship) can only influence practice when they are reduced to forms which can be accommodated within existing systems and priorities (Marcuse, 1991). A perfect example is the operationalisation of economic citizenship (if that is what it is) through the techniques and economic concerns of the managerial specialists at Caterpillar, as described in the foregoing quotation.

In assimilating the concept of new economic citizenship to the practicalities of the new manufacturing, Miller and O’Leary were following well-established precedents. A case in point is the research of the MIT Commission, their first cited source for the concept. An output of that research was an authoritative use of language which identified the new economic citizenship with conditions which actually existed in leading US companies, a kind of backdoor operationalism which deprived the concept of most of its critical edge.

Despite its show of theoretical sophistication, Miller and O'Leary's procedure is effectively the same. Having left the definition of new economic citizenship offstage throughout their paper, they are able to use the resulting conceptual slack to assert, without arguing the matter point by point, that what they observed in Caterpillar amounted to an enactment of it.

In one respect, indeed, Miller and O'Leary's procedure could be said to be less critical than the Commission's, since the very process of averaging ensured that conditions in some companies will fall short of new economic citizenship. The encouragement of 
reform in such companies, indeed, was the whole point of the study. Miller and O'Leary's single company study, by contrast, affords no such leverage. What would conditions have had to be like at Caterpillar, one wonders, for Miller and O'Leary to have found them incompatible with new economic citizenship? Recall that the story told to Arnold by the workers was one of continuing job losses, increased workloads, deteriorating conditions of employment and the loss of trade union rights. Miller and O'Leary themselves tell us that the PWAF programme was accompanied by 'an aggressive outsourcing programme' in which low-technology labour intensive processes were subcontracted out to 'focussed, lower cost suppliers'. How much of this counts as an enactment of new economic citizenship? In order to confront such questions, there would have to be a definition of economic citizenship, either that of the 'commentators' to which Miller and O'Leary refer, or one of their own. But since they do not offer one, and since they also believe its empirical content to be defined, at least in part, by its enactment at Caterpillar, they would seem to have set an examination which cannot be failed.

\section{Into Battle with the Jeddak of Lothar}

Like science fiction, writings of the post-Foucaultian 'governmentality' school tend to feature hypothetical beings. For the social analyst, they are a means of explicating the thinking behind systems of government or control. Since all such systems are intended to produce certain behavioural and attitudinal outcomes, it is not unreasonable to discuss them in terms of the kinds of people envisaged in their design - 'governable persons' in Miller and O’Leary (1987) or 'economic citizens' as in the present case. Handy in moderation, the excessive use of this rhetorical device can weaken a person's grasp on reality. As usual, the science fiction writers were early on the case.

In Edgar Rice Burroughs’ benchmark politically incorrect Thuvia, Maid of Mars, the part of the idealist is played by Tario, Jeddak of Lothar. Insisting that matter is nonexistent except in the imagination of man, Tario puts his beliefs to practical use by materialising an army of bowmen using the unaided power of suggestion. So frequently does he do so, and with such conviction, that Kar Komak, Odwar of the Bowmen finds himself permanently materialised. Flushed with this success, Tario now maintains the suggestion of a beautiful girl hidden in a secret cell within his palace, hoping that she too will become permanent. As a product of Tario's evil mind none knows better than Kar Komak, the fate which awaits her. 'For her sake,' he shudders, 'I hope that Tario succeeds not so well with her as he has with me.'

The extended discussions of hypothetical beings which haunt post-Foucaultian scholarship have something of the same effect. With each invocation, they seem a little more distinct, a little more tangible. Thus Miller and O’Leary's story progresses from 'hopes of a new competitiveness and a new mode of economic citizenship' [italics added] to such statements as 'accounting helps to make operable the demands and aspirations of the "new economic citizenship"”. Through repeated imaginings, the new economic citizens begin to acquire agency as well as mass, thereby augmenting their reality. The overall effect is one of idealism by stealth, a style of writing in which incantation takes over the work of research.

But suppose Tario only imagines that he has materialised the perfect woman. Where then is the harm ? Perhaps we should leave the practitioners of sociological idealism to their intricate solace. Perhaps, on the other hand, we should think of the real hardships played out behind their projections of economic citizenship. 


\section{Citizenship, Democracy and Newspeak}

However Miller and O'Leary, and the MIT Commission before them, seek to hollow out the concept of citizenship so that it can be attached to the practice of 'soft' Human Resource Management (Storey, 1992), it is an ordinary language concept which is not empty of content. On the contrary, it is remarkably resilient and full of democracy. Viz:

Citizen: A member of a state, an enfranchized inhabitant of a country, as opp. to an alien; in U.S. a person, native or naturalized, who has the privilege of voting for public offices, and is entitled to protection in the exercise of private rights.

Shorter Oxford English Dictionary 1960

Once the connection between citizenship and democracy is restored, we can begin to situate contemporary discussions of economic citizenship against the long tradition of social democratic debate on what forms industrial democracy might take in capitalist economies (e.g. Cole, 1917). In the post-war UK and Western Europe these debates have revolved around questions of worker representation on company boards, joint consultative committees and around the extent to which collective bargaining through elected trade union representatives can itself function as a form of industrial democracy (Clegg, 1951: pp. 24, 131). Whatever position one takes on these issues, it is clear that the conception of citizenship which Miller and O'Leary extract from the MIT Commission's report and purport to find in Caterpillar falls woefully short of any of them. From this perspective, their writing can be located within a continuing project of reworking the language so that economic citizenship will come to signify a lesser good than even the mild ameliorations of economic power conveyed by the term citizenship itself. The end point of this operationalisation of the language of critique, like that of Orwellian Newspeak, is a closure of critical thought in which what is possible is contained within what is. It is in this manner that methodological idealism serves the ends of political ideology, and it is the task of critical social science, including critical accounting, to unmask the connection

\section{Conclusions: Some Language Games of Ideology}

So how is the trick accomplished? Froud et al note the skill with which Miller and O'Leary translate management information into the idiom of post-Foucaultian scholarship, thereby inflating it into a paper of almost 13,000 words. In fact their stylistic idiosyncrasies are more consequential than this. Essentially they are ways of writing the data so that their preferred conclusions can be argued from it without constraint. In this manner, the credibility of empirical research ('finding things out') can be attached to what is really imaginative writing. In general the language forms through which this is achieved work by erasing distinctions which we would normally make in reading everyday situations. As a way of writing social science, it involves a degradation of commonsense understandings, not a sharpening of them. Some examples are:

\section{Persistent use of the Passive}

The passive voice is normally used when what is done is more important than who does it. Research in the natural sciences is a frequently quoted example. It is a 
condition which rarely holds in the social sciences. As Pat Arnold pointed out at the 1999 Critical Perspectives in Accounting Conference, the persistent use of the passive voice erases some of their most basic data: that of who is acting, interpreting and reacting. Thus Miller and O'Leary have much to say about the meanings of the Plant with a Future programme at Caterpillar, but nothing at all about whose meanings those were. Yet a positive evaluation from a management consultant, for example, signifies something very different to one from an employee.

In the uncertainty created by persistent use of the passive, moreover, there is no way of distinguishing the interpretations of the writers from those which are in the data. In effect, Giddens' double hermeneutic collapses into a confusion in which all we know is that interpretation is taking place. At crucial points in their argument, this confusion leads Miller and O'Leary to read their own interpretations as if they were part of the data, possibly without realising they have done so. It is in this manner that they effect the connections, vital to the central theme of their paper, between the new economic citizenship, the changes at Caterpillar and the spatial re-ordering of manufacture.

\section{Absent Definitions}

The number of key concepts and possible modes of connection which are left undefined in Miller and O'Leary's prose is extraordinary. So is their wholesale use of inverted commas to disrupt normal meanings without substituting others. At the logical limit, of course, such a vacuum of definition allows statements of connection to be made on a whim. If both new economic citizenship and alignment are undefined, for example, I can say that it is aligned with a banana. Later, as with invisible ink, the residual meanings re-appear so that something turns out to have been said after all, both about citizenship and bananas.

\section{Hypothetical Beings}

The prose of 'governmentality' has much to say of hypothetical beings personifications, that is, of the attributes assumed by our governments in the design of their control systems. In Miller and O’Leary's case, this stylistic heritage leads to forms of words which blur the distinction between these entities and real people. Since part of the aim of reform programmes is to make people think and behave like imagined prototypes, the consequence of this lack of clarity is a tendency to confuse the intentions of these programmes with outcomes. When we are told that, 'a new type of economic citizen is called upon to act', for instance, it is not clear whether or not it is being said that these citizens actually exist. If it is, that is an outcome and we are being told something about the way people have been changed. If it is not, that is an intention and we are being told something about a programme intended to change

them. It is a confusion which allows Miller and O'Leary to write an account of a managerial wish-list and be read as if they were writing about socially momentous changes.

\section{Postscript}

Whilst preparing this paper, I received an e-mail from Professor Tony Tinker of City University New York. Part of it reads as an appropriate epitaph for the hopes of those who went along with Caterpillar's 'Plant with a Future' programme. 
‘. . Did you know that when Caterpillar finally abandoned Decatur, they insisted on leaving a rusting monument by the highway as a reminder to the unions and the local community not to mess with corporations? I've asked a friend to try to get a photo of it next time he drives through.'

\section{References}

Amin, Ash (1989) A Model of the Small Firm in Italy Ch. 3 in Ch. 1 in Goodman, E. and Bamford, J. (Eds.) Small Firms and Industrial Districts in Italy. pp. 111-120

Arnold, P.J. (1998) The limits of postmodernism in accounting history: The Decatur experience. Accounting Organizations and Society, Vol.23, No.7, pp.665-684.

Bhaskar, R. (1986) Scientific Realism and Human Emancipation. London. Verso.

Blim, Michael L. (1990) Made in Italy: Small-scale Industrialization and its Consequences. New York: Praeger.

Clegg, H. A. (1951) Industrial Democracy and Nationalisation. Oxford. Blackwell.

Cole, G.D.H. (1917) [1972] Self-Government in Industry. London: Hutchinson.

Denzin, N.K. (2000) The Practices and Politics of Interpretation. Ch. 35 in N. K.

Denzin \& Y. S. Lincoln (Eds.), Handbook of Qualitative Research (pp. 923-948).

Thousand Oaks, CA: Sage. pp. 897-922.

Dertouzos, M.L., Lester, R.K. and Solow, R.M. (1989) Made in America: Regaining the Productive Edge. Cambridge MA. MIT Press.

Dertouzos. Michael L. (1997) What Will Be: How the New World of Information Will Change Our Lives. London. Piatkus.

Edwards, R.C. (1979) Contested Terrain: the Transformation of the Workplace in the Twentieth Century. London. Basic Books.

Friedman, A (1977) Industry and Labour: Class Struggle at Work and Monopoly Capitalism. London. Macmillan

Froud, J., Wllliams, K., Haslam, C., Johal, S. and Williams, J. (1998) Caterpillar: Two stories and an argument. Accounting Organizations and Society, Vol.23, No.7, pp.685-708.

Harrison, Bennett (1994) The Italian industrial districts and the crisis of the cooperative form: Part II. European Planning Studies, Vol. 2 Issue 2, pp. 159-173.

Hesse, M. (1974) The Structure of Scientific Inference. London. MacMillan

Hirst, R.P. and Zeitlin, J. (1991) Flexible Specialisation versus Post-Fordism: Theory, Evidence and Policy Implications. Economy and Society. pp. 1-56.

Inzerilli, Giorgio (1990) The Italian Alternative: Flexible Organization and Social Management. International Studies of Management and Organization, Vol. 20, No. 4, Winter 1990, pp. 6-21.

Johnson, H.T. (1992) Relevance Regained: from Top-Down Control to Bottom-up Empowerment. New York. Free Press.

Marcuse, Herbert (1991) One-Dimensional Man: Studies in the Ideology of Advanced Industrial Society $2^{\text {nd }}$ ed. London. Routledge. 
Miller, P. and O'Leary, T. (1987) Accounting and the Construction of the Governable Person. Accounting, Organisations and Society. Vol 12. No 3. pp. 235-265.

Miller, P. and O'Leary, T. (1994) Accounting, "Economic Citizenship” and The Spatial Reordering of Manufacture. Accounting Organizations and Society, Vol.19, No.1, pp.15-43

Miller, P. and O'Leary, T. (1998) Finding things out. Accounting Organizations and Society, Vol.23, No.7, pp.709-714.

Sabel, C. (1991) Moebius-Strip organizations and Open Labor Markets. in Bourdieu, P. and Coleman, J.S. (Eds.) Social Theory for a Changing Society. Boulder CO. Westview Press.

Storey, J. (1992) Developments in the Management of Human Resources. Oxford. Blackwell.

Taylor, P.L. (1999) Qualitative cowboy or qualitative dude: An impasse of validity, politics, and ethics? Sociological Inquiry, Vol. 69, No. 1, pp. 1-32.

Times Higher Education Supplement 20 ${ }^{\text {th }}$ April 2001 p. 25 